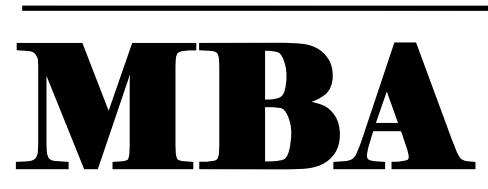

Vol. 4 , No. 2 , July 2021, page 436 - 444

ISSN 2614-1981 (Print)

ISSN 2615-0352 (Online)

Journal of Management and Business Aplication

\title{
THE INFLUENCE OF SERVICE QUALITY ON COMMUNITY SATISFACTION IN THE MAKING OF E-KTP IN LUMAJANG REGENCY
}

\author{
Tomy Ernawati ${ }^{1}$ \\ Suwignyo Widagdo ${ }^{2}$ \\ Yuniorita Indah Handayani ${ }^{3}$ \\ Lumajang District Government \\ Email: tomycaem18@gmail.com
}

\begin{abstract}
This study aims to determine the quality of services to community satisfaction for making EKTP in Sumbersuko District, Lumajang Regency. This research was conducted in Sumbersuko District, Lumajang Regency. The population in this study is the people in Sumbersuko Subdistrict who already have E-KTP with totaling 27,306 people. The sampling method uses simple random sampling with questionnaire distribution techniques. The number of samples in this study was 125 respondents spread in Sumbersuko District. The method of data analysis in this study used multiple linear regression analysis with the help of SPSS 20.0 software. Based on the results of data analysis shows that the variable responsiveness, assurance, and empathy have a significant effect on community satisfaction with the value of the influence of respectively $27.3 \%, 30.5 \%$, and $14.3 \%$. While the tangible and reliability variables did not significantly influence community satisfaction in making E-KTP in Sumbersuko District, Lumajang Regency. This result also shows that the assurance variable is the most dominant variable influencing community satisfaction in making E-KTP in Sumbersuko District, Lumajang Regency.
\end{abstract}

Keyword: Service Quality, Community Satisfaction, E-KTP

\section{INTRODUCTION}

According to Law No. 25 of 2009 concerning public services, namely the Act that regulates the principles of good governance which is the effectiveness of the functions of the government itself. The rapid growth of the economy and welfare has resulted in people wanting better services. Community service reflects the whole approach of the government apparatus. The essence of community service is a helpful, friendly, and professional attitude in providing services or products. The main function of the government is to provide public services which in turn will be available and well implemented and satisfy the community.

In public services, in general, the government regulates public goods and semi-public goods. In general, the implementation of public service activities includes a wide and complex 
implementation environment, complicated and in the process contains activities that are interrelated with activities or tasks and functions between units/agencies with one another (Bambang, 2011). The substance of public services is always associated with an activity carried out by a person or group of people or certain agencies to provide assistance and convenience to the community in order to achieve certain goals. This public service is becoming increasingly important because it is always in touch with people who have a variety of interests and goals.

According to Kotler (Ahaditya, 2015), service is any activity that is profitable in a group or entity, and offers satisfaction even though the results are not tied to a physical product. Public services are all service activities carried out by public service providers as an effort to fulfill public needs and implement statutory provisions (Mahmudi, 2010). According to Article 5 of Law Number 25 of 2009 concerning Public Services, namely, the scope of public services includes public goods and public services as well as administrative services regulated in laws and regulations. One of them is public services.

According to Fandy, Tjiptono and Anastasia Diana, (2003) identified five characteristics used by residents in evaluating service quality, namely: Tangible dimension (physical evidence), Reliability dimension (reliability), Responsiveness dimension (responsiveness), Assurance dimension (assurance). ), and the Empathy dimension (empathy). Tangible dimension is characterized by the provision of adequate services and other resources. Reliability dimension is that a good service is characterized by proper and correct service. The Responsiveness dimension is characterized by the desire of officers to serve the community. The Assurance dimension is characterized by the behavior of officers in serving the interests of the community and being able to foster trust from the community. The Empathy dimension is characterized by the willingness of service officers to understand problems and act in the interests of the community and provide personal attention to the community.

Making Electric Identity Card (EKTP) services in the District (Nurul, 2015) . E-KTP or Electric Resident Identity Card is the new name of the Resident Identity Card whose data is taken directly in the District using a computer. In the process, the data is sent to Jakarta and then printed at the Population and Civil Registry Office and then distributed to the public as a new identity card, so that there is no duplicate identity card. The creation of an E-KTP is free of charge and wide open to residents. However, in reality the implementation of E-KTP services in several regions in Indonesia is still experiencing problems. These obstacles include there are still people who have not received an E-KTP because the process is long, complicated/difficult, the existence of a bureaucratic structure in the procedures for issuing an E-KTP, a problematic server system, inadequate facilities and infrastructure, lack of attention and good response. for employees, and so on. The public service image of government officials can be judged from small things, for example when we are making or managing an E-KTP, it can be an early indicator of the quality of population services from sub-district government institutions.

Good service quality is service that is in accordance with established service procedures, namely in Standard Operating Procedures (SOP) and Minimum Service Standards (SPM) in making the E-KTP. Good Standard Operating Procedures (SOP) and Minimum Service Standards (SPM) can be a guide for sub-district officers in 
providing services and to maintain consistency, as a reference in implementing activities, and avoiding mistakes or failures in sub-district officers providing services. To measure a community's satisfaction with the making of an Electric Identity Card (EKTP). According to Eka's research (2018), the reliability and assurance variables have a positive and significant effect on community satisfaction as patients, while the responsive, empathy, and physical evidence variables have a positive and insignificant effect on satisfaction. Meanwhile, according to Hidayah's research (2012) concluded that the service quality variable consisting of the clarity of service officers and the security of the service environment had a significant effect on community satisfaction.

Sumbersuko Subdistrict, Lumajang Regency whose job is to serve the general public in the field of government such as making Family Cards, Electric Identity Cards (E-KTP), marriage certificates, and so on are still not optimal in their services because there are several things that need to be addressed including the quality of resources. human resources that need to be improved and computer hardware that often experiences problems, including the software, namely the online E-KTP software from the center which is often problematic, resulting in services that are not optimal, such as the wrong time in completing the EKTP which is too long and procedures which is convoluted, resulting in public disappointment. Based on the problems and descriptions above, this study aims to determine the quality of service to community satisfaction in making E-KTP in Sumbersuko District, Lumajang Regency.

Research on service quality has been carried out by Sinaga (2016), the results of this research state that of the five service quality variables only tangible and empathy dimensions affect people's satisfaction; the second service quality variables such as tangible, reliability, responsiveness, assurance, and empathy simultaneously affect public satisfaction, the three most dominant variables from the influence of PATEN service quality on public satisfaction are empathy variables. In addition, Ulumudin (2014) stated that descriptively the quality of population administration services in Bayongbong District was quite good and community satisfaction was categorized as quite good. The results also show that service quality has an influence on community satisfaction in Bayongbong District.

Susila (2010) in her research states that responsiveness, physical evidence, credibility and empathy have a positive and significant effect on people's satisfaction. In this study, it was found that the empathy variable had the most dominant influence on people's satisfaction. Mahardika (2018) in his research shows that the simultaneous influence of variables consisting of physical evidence of reliability, responsiveness, assurance and empathy affects community satisfaction at the Kenjeran District Office, Surabaya. In addition, Eka (2018) in the results of his research shows that reliability, responsiveness, certainty, attention and physical evidence simultaneously have a positive and significant effect on community satisfaction as a patient.

In previous studies, community satisfaction was consistently influenced by the variables of tangibility, reliability, Responsiveness, Assurance, and Empath. So the research is now conducted to prove whether the five variables are still relevant to be used to determine community satisfaction in 2019 with a different object, namely in Sumbersuko District, Lumajang Regency.

\section{RESEARCH METHODS}

The research used by the researcher is descriptive research with a quantitative approach. This research was conducted in 
Sumbersuko District, Lumajang Regency. The population in this study is the people in Sumbersuko District who already have an EKTP totaling 27,306 people. The sampling method used simple random sampling with questionnaire distribution techniques. The number of samples in this study were 125 respondents spread across Sumbersuko District. The sampling technique used in this study is a non-probability sampling technique, namely the Accidental Sampling approach. Accidental Sampling is a technique of determining samples based on chance, that is, anyone who coincidentally meets a researcher can be used as a sample if it is deemed that the person who happened to be met is suitable as a data source (Sugiyono, 2012: 67). The variables in this study consisted of five independent variables, namely Tangible (X1), Reliability (X2), Responsiveness (X3), Assurance (X4), and Empathy (X5) and one dependent variable was community satisfaction (Y).

The data analysis method in this study used multiple linear regression analysis with the help of SPSS 20.0 software. it aims to determine the effect of service quality (tangibles, reliability, responsiveness, assurance and empathy) on community satisfaction in Sumbersuko sub-district in the management of e-ID cards using multiple linear regression analysis. Before performing multiple linear regression analysis, the validity and reliability of the data were first tested with the aim of knowing how valid the data obtained from the questionnaire distribution was and to find out the extent to which the measurement results remained consistent, if two or more measurements were taken of the same symptoms using a tool. the same gauge. To find out the partial relationship between the independent variable and the dependent variable, a hypothesis test was conducted using the t-test. Meanwhile, to find out simultaneously the test is carried out using the $\mathrm{F}$ test.

\section{RESULT ANALYSIS}

\section{Data Validity Test}

The validity of the research instrument was tested by distributing questionnaires to 125 respondents at the time of the study. The validity test was carried out through item analysis with the Pearson product moment correlation formula which was calculated using SPSS version 21.0 software. Based on the calculation of the validity of the research data instrument, the results obtained that 24 indicators or question items from the Tangibles (X1), Reliability (X2), Responsiveness (X3), Assurance (X4), Empaty (X5) and Satisfaction variables $(\mathrm{Y})$ variables are all valid. because the value of the total item correlation coefficient (r-count) exceeds 0.30 with a significance level of $\mathrm{p}<0.05$. The significance test of the validity of the instrument was also carried out by comparing the r-count value with the r-table for degree of freedom $(\mathrm{df})=\mathrm{N}-2$ in this pretest the number of samples (n) was 125 so that the magnitude (df) was 119 with a significance level of 5\% then it is known that the value of $r$-table is 0.150 . Based on the table above, it is proven that all indicators can be validated because all $\mathrm{r}$ count values are greater than r-table, in other words, the questions in this study can be declared feasible to be used in research.

\section{Reliability Test}

The reliability test was conducted to obtain the level of accuracy of the research data collection tools used. The test results in the table show that the value of the reliability coefficient (Cronbach's alpha) on the Satisfaction variable $(\mathrm{Y})$ is 0.834 , meaning that the Cronbach's alpha value is more than 0.60 . In other words, the indicator of satisfaction variable in this study can be 
trusted. Likewise for other variables, the research data instrument gives a cronbach alpha value on the Tangibles variable (X1) of 0.825 ; Reliability (X2) is 0.832, Responsiveness (X3) is 0.832, Assurance (X4) is 0.833, Empathy (X5) is 0.672, this means that all indicators used as measuring variables in this study can be trusted because each has a Cronbach alpha value. more than 0.60 .

\section{Data Normality Test}

Normality test is conducted with the aim of testing whether in a regression model, the independent and dependent variables or both have a normal distribution or not. Based on the results of normality testing of data through SPSS 21.0 software, it can be seen that the data spreads around the diagonal line and follows the direction of the diagonal line, so that the regression model meets the assumption of normality. The results of the data normality test can be seen in Figure below:

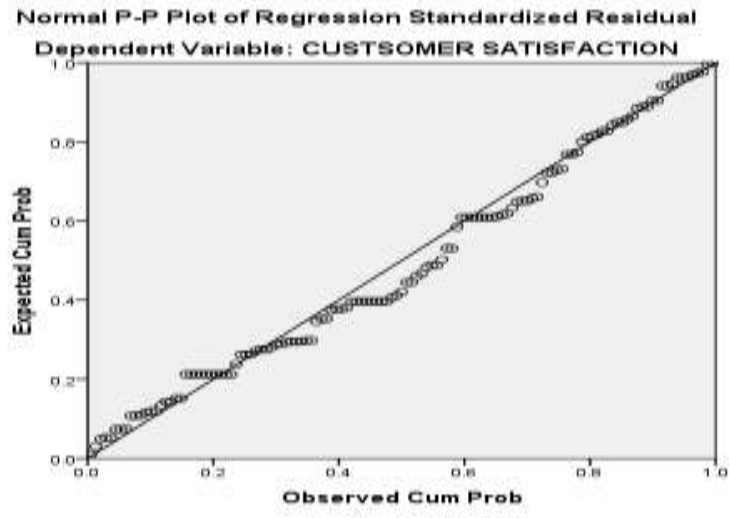

Figure 1. Normality Test

\section{Multicollinearity Test}

Multicollinearity test was conducted to test whether the regression model found a correlation between the independent variables or not. A good regression model is if there is no correlation between variables. The results of the Multicollinearity Test can be seen in the table. following:

Table 1. Multicollinearity Test

\begin{tabular}{cccc}
\hline Variable & VIF & Tolerance & Information \\
\hline$X_{1}$ & 3,208 & 0,312 & \\
$X_{2}$ & 3,500 & 0,278 & \\
$X_{3}$ & 3,515 & 0,284 & VIF $<10$ \\
$X_{4}$ & 3,033 & 0,330 & \\
$X_{5}$ & 1,260 & 0,794 & \\
\hline
\end{tabular}

From the results of table shows that the regression model has a VIF value of each variable less than the number 10 . It can be concluded that the regression model in this study does not occur multicollinearity symptoms. 


\section{Heteroscedasticity Test}

This assumption states that whether in the regression model there is an inequality of variance from one residual to another observation. If the variance of one residual of one other observation remains, it is called homoscedasticity. Based on the image of the results of the Heteroscedasticity Test, it can be seen that the test results describe no clear pattern, the points spread above and below the number 0 on the $\mathrm{Y}$ axis. So it can be concluded that in the regression model there are no symptoms of heteroscedasticity. The test results can be seen in Fig. 4.2 following:

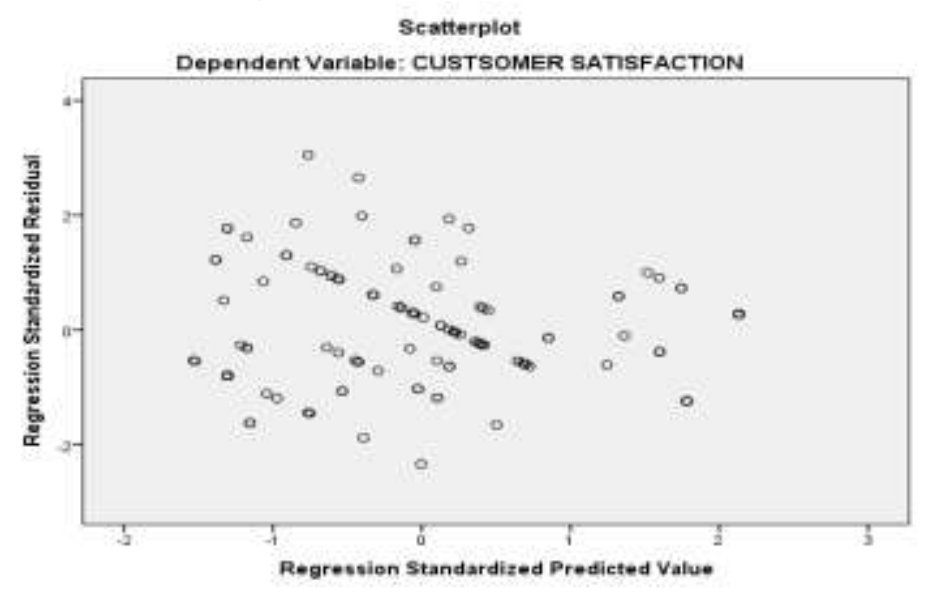

Figure 2. Normality Test

\section{Multiple Linear Regression Analysis}

In analyzing the data in this study, the method used by researchers to find out is multiple linear regression analysis. This analysis aims to determine the simultaneous effect of tangibles, reliability, responsiveness, assurance and empathy variables on community satisfaction in making (E-KTP) in Lumajang Regency. In addition, this analysis also aims to determine the partial effect of tangibles, reliability, responsiveness, assurance and empathy variables on the variable of community satisfaction in making (E-KTP) in Lumajang Regency.

The process of calculating multiple linear regression analysis in this study uses SPSS version 21.0 software. The coefficient value indicated by the SPSS output value called the Coefficient is expressed as the Standardized Coeffitient or known as the Beta value.

Table 2. Multiple Linear Regression Analysis

\begin{tabular}{|c|c|c|c|c|c|c|c|}
\hline \multirow[t]{2}{*}{ Model } & \multicolumn{2}{|c|}{$\begin{array}{c}\text { Unstandardized } \\
\text { Coefficients }\end{array}$} & \multirow{2}{*}{$\begin{array}{c}\begin{array}{c}\text { Standardized } \\
\text { Coefficients }\end{array} \\
\text { Beta }\end{array}$} & \multirow[t]{2}{*}{$\mathrm{t}$} & \multirow[t]{2}{*}{ Sig. } & \multicolumn{2}{|c|}{$\begin{array}{c}\text { Collinearity } \\
\text { Statistics }\end{array}$} \\
\hline & $\mathrm{B}$ & Std. Error & & & & Tolerance & VIF \\
\hline (Constant) & 3.754 & .980 & & 3.832 & .000 & & \\
\hline TANGIBELITY & .153 & .110 & .146 & 1.394 & .166 & .312 & 3.208 \\
\hline RELIABILITY & .037 & .109 & .038 & .339 & .736 & .278 & 3.600 \\
\hline RESPONSIVENESS & .260 & .104 & .273 & 2.493 & .014 & .284 & 3.515 \\
\hline ASSURANCE & .280 & .093 & .305 & 2.997 & .003 & .330 & 3.033 \\
\hline EMPATHY & .060 & .028 & .143 & 2.178 & .031 & .794 & 1.260 \\
\hline
\end{tabular}


Based on the table above, it can be explained that the tangibles variable (X1) has no significant effect on community satisfaction (Y) in making (E-KTP) in Lumajang Regency, the reliability variable (X2) has no significant effect on community satisfaction (Y) in making (E-KTP) KTP) in Lumajang Regency, Responsiveness variable (X3) has a significant effect on community satisfaction $(\mathrm{Y})$ in making (EKTP) in Lumajang Regency, Assurance variable (X4) has a significant effect on community satisfaction $(\mathrm{Y})$ in making (EKTP) in Lumajang Regency, the Empathy variable (X5) has a significant effect on community satisfaction (Y) in making (E$\mathrm{KTP}$ ) in Lumajang Regency.

\section{Coefficient of Determination}

The Coefficient of Determination $\left(\mathrm{R}^{2}\right)$ is carried out to see whether there is a perfect relationship or not, which is indicated by whether changes to the independent variables (Tangibles, Reliability, Responsiveness, Assurance, Empathy will be followed by the dependent variable (Society Satisfaction) in the same proportion. The results of the coefficient of determination can be seen in the following table.

Table 3. Model Summary

\begin{tabular}{llrrr}
\hline Model & R & R Square & $\begin{array}{c}\text { Adjusted R } \\
\text { Square }\end{array}$ & $\begin{array}{l}\text { Std. Error of } \\
\text { the Estimate }\end{array}$ \\
\hline 1 & $.770^{\mathrm{a}}$ & .593 & .576 & 1.557 \\
\hline
\end{tabular}

Based on the table above, it can be seen that the Adjusted R2 value is 0.576 . This means that the independent variables consisting of tangibles, reliability, responsiveness, assurance, empathy can explain the dependent variable in this case community satisfaction of $57.6 \%$. While the rest is influenced by other variables that are not included in this study.

\section{INTERPRETATION}

Based on the results of multiple linear regression analysis shows that the tangibles and reliability variables have no significant effect on community satisfaction in making (E-KTP) in Lumajang Regency. The results of this study reject the findings of research conducted by Sinaga (2016) and Ulumudin (2014) which state that the tangibility variable has a significant effect on community satisfaction.

The results of this study also indicate that the variables Responsiveness, Assurance and Empathy have a significant effect on community satisfaction in making (E-KTP) in Lumajang Regency. These results support the findings of research conducted by Sinaga (2016) which states that the responsiveness variable has a significant effect on community satisfaction. The same thing was also expressed by Pratiwi (2018) which stated that the responsiveness variable had an effect on community satisfaction. In addition, these results also support the research findings of Ulumudin (2014) and Marhadika (2013) which state that the responsiveness variable has a significant effect on community satisfaction.

In realizing quality public services, it is necessary to make changes and improvements that lead to community satisfaction. One aspect that must be improved in improving the quality of service is the problem of service facilities. The role of service facilities is very important in improving the quality of public services because with adequate service facilities it can make services to the community more comfortable and satisfying while in the service room. Regarding the completeness of the equipment and waiting room facilities 
at the Civil Service Office of Lumajang Regency, it is not yet complete, especially for chairs and tables for waiting, information facilities such as brochures and pamphlets are not yet available. Supporting facilities such as photocopying machines are not yet available and the use of generators during power failures has not been optimized. From the results of the study, it is known that the Service Office for making E-KTP Lumajang Regency has not fulfilled adequate service facilities to provide services to the community such as the lack of chairs in the waiting room, the absence of a table for writing in the waiting room, information facilities that are not yet available. Facilities such as generators are not optimized so that when the electricity goes out, the service process will also stop completely, which means that people cannot get services.

The increasing public need for this service needs to be balanced with maximum and fast service which requires the apparatus to be nimble in their work. Reliability is the ability to provide the promised service immediately, accurately and satisfactorily, such as timeliness, speed and accuracy in service completion. In providing services to the public, reliability and professionalism in providing a service immediately, accurately and satisfactorily are very necessary in order to create satisfaction in customers. The ability of a service provider government agency to provide services as promised in a timely, accurate, and reliable manner and provide the same service is one of the important elements that service providers must possess.

Responsiveness of employees is very much needed in public services because this is evidence and concrete actions taken by the organization in responding to and recognizing the needs and aspirations of the community. Responsiveness here can mean the response or alertness of officers in helping people who need services. From the results of the study, it was found that the responsiveness of the service officers of the Lumajang Regency E-KTP manufacturing service office was quite good. This is indicated by the existence of mutual communication and coordination between officers and the community regarding the completeness of the files that the community brings when making ID cards. In addition, most of the community stated that service officers were responsive always helped explain any difficulties experienced by the community during the process of making ID cards. This shows that the responsiveness provided by the KTP-making service office in Lumajang Regency is in accordance with what the community expects.

A guarantee becomes important in the service office environment for making ID cards, considering the number of people who need services for making ID cards. They should get comfort during service. Apart from guaranteeing the security of the service environment, there is no less important, namely the existence of a definite guarantee for the applicant for population administration with the capabilities provided by the agency, so that they feel satisfied. In this case, the competence of public service providers must be based on the required knowledge, expertise, skills, attitudes and behaviors. KTP making service officers in Lumajang Regency have made maximum efforts to carry out their duties properly, if there are complaints from the community the service officers can immediately follow up, so that people feel satisfaction from the guaranteed services provided by the Lumajang Regency KTP making service office.

Empathy is a sense of caring to give attention to the community for the needs that are in need of service. As a public agency that provides services, it is required to always be ready to help people who need services. The concern of employees to 
always prioritize the needs of the community will support the creation of quality public services. According to the community the willingness of the officers to serve in my opinion is quite good. From the results of interviews with the community, it can be seen that the problem of the willingness of officers to serve the community is good with many public responses stating that they are quite good. Providing services, the willingness of the apparatus to provide information is something that needs attention. The willingness of employees to provide information to people who need services will be able to improve the way of service in the eyes of the community. So that in creating excellent public service, it is necessary to support employees who are empathetic in helping the needs of people who need information.

\section{CONCLUSION}

Based on the results of the discussion described above, it can be concluded that the variables tangible, reliability, responsiveness, assurance and empathy simultaneously affect people's satisfaction in making E-KTP in Lumajang Regency. Based on the results of multiple linear regression analysis shows that the tangibles and reliability variables have no significant effect on community satisfaction in making (E-KTP) in Lumajang Regency. The results of this study also indicate that the variables Responsiveness, Assurance and Empathy have a significant effect on community satisfaction in making (E-KTP) in Lumajang Regency.

\section{REFERENCES}

Marhadika, 2013, Pengaruh Kualitas Layanan Terhadap Kepuasan Masyarakat di Kantor Kecamatan Kenjeran Surabaya, Jurnal

Pratiwi et all, 2018, Pengaruh Kualitas Layanan Terhadap Kepuasan Masyarakat sebagai Pasien di Puskesmas Sering, Repositori Institusi USU

Sinaga et all, 2016, Pengaruh Kualitas Pelayanan Terhadap Kepuasan Masyarakat dalam Pelaksanaan Program Pelayanan Administrasi Terpadu Kecamatan (Paten) di Kecamatan Nongsa Kota Batam, Jurnal Akuntansi, Ekonomi dan Manajemen Bisnis, Vol 4 No 1 pISSN: 2337-7887, Politeknik Negeri Batam.

Sugiyono. 2009. Metode Penelitian Bisnis. Penerbit CV. Alfabeth. Bandung.

Susila, 2010, Analisis Pengaruh Kualitasi Pelayanan Kantor Kelurahan Terhadap Kepuasan Masyarakat Kelurahan Jagalan Kecamatan Jebres Kota Surakarta, Journal of Rural and Development Vol 1 No 1, STIE-AUB, Surakarta

Ulumudin, 2014, Pengaruh Kualitas Pelayanan Administrasi Kependudukan terhadap Kepuasan Masyarakat Kecamatan Bayongbong Kabupaten Garut, Jurnal Pembangunan dan Kebijakan Publik, ISSN: 2087-1511, Fakultas ISIP, Universitas Garut. 